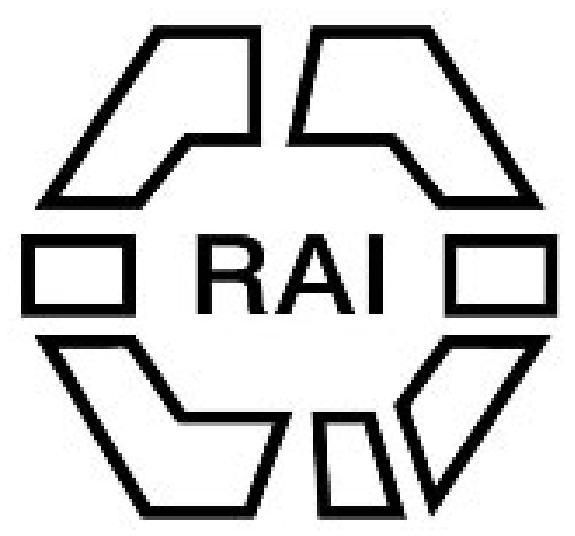

Notes on the Occurrence of Stone Implements in the Valley of the Zambesi around Victoria

Falls

Author(s): G. W. Lamplugh

Source: The Journal of the Anthropological Institute of Great Britain and Ireland, Vol. 36

(Jan. - Jun., 1906), pp. 159-169

Published by: Royal Anthropological Institute of Great Britain and Ireland

Stable URL: http://www.jstor.org/stable/1193253

Accessed: $15 / 06 / 2014$ 13:28

Your use of the JSTOR archive indicates your acceptance of the Terms \& Conditions of Use, available at http://www.jstor.org/page/info/about/policies/terms.jsp

JSTOR is a not-for-profit service that helps scholars, researchers, and students discover, use, and build upon a wide range of content in a trusted digital archive. We use information technology and tools to increase productivity and facilitate new forms of scholarship. For more information about JSTOR, please contact support@ jstor.org. 


\section{NOTES ON THE OCCURRENCE OF STONE IMPLEMENTS IN THE VALLEY OF THE ZAMBESI AROUND VICTORIA FALLS.}

By G. W. Lamplugh, F.R.S., F.G.S.

[With Plate XV.]

\section{Introduction.}

WHILE investigating the geology of the Zambesi Valley around the Batoka Gorge below Victoria Falls on behalf of the British Association in July and August, 1905, I noticed that in many places rudely chipped implements of chalcedony and chert occurred in great profusion on the rocky surface. Though unable to devote the time necessary for the proper study of these relics during my traverse of the country, I took note of the localities in which they were conspicuously present, and made a small collection which I exhibited to the Anthropological Section of the Association during the meeting at the end of August, 1905, in Johannesburg. ${ }^{1}$ Since that time other collections have been made, and descriptions of the implements from the immediate vicinity of the Falls have been given by Colonel H. W. Feilden ${ }^{2}$ and by Mr. J. P. Johnson. ${ }^{3}$ And, as the subject is likely to be of interest to anthropologists, from the possibility that some of the implements may be of high antiquity, it seems desirable that, in bringing those which I collected to the notice of the Anthropological Institute, I should describe the conditions under which these relics were found.

\section{Physiographical Conditions.}

The Zambesi River, immediately above the Victoria Falls, flows in a broad shallow valley bounded on both sides by rising ground which represents the slightly worn margin of the great central plateau. At the crest of the Falls the river is a mile in width, but after its great plunge its waters are gathered into a narrow gorge only about 150 yards wide, with nearly vertical walls about 400 feet in height. This gorge, gradually widening at the top from the weathering back of its walls, is prolonged for a distance of over sixty miles below the Falls, beginning in a very remarkable series of acute zigzags; and it is characterised throughout by sharp changes of course, which do not, however, affect the broadly sweeping curves of its general direction. (Fig. 1.) Until recently, the "Batoka Gorge," as I have

1 This collection, including the specimens figured in Plate XV, has been presented to the Department of British and Mediæval Antiquities and Ethnography of the British Museum (Bloomsbury).

2 Nature, vol. lxxiii, Nov. 23rd, 1905, p. 77.

${ }^{3}$ Trans. Geol. Soc. S. Africa, vol. viii, in the press. 
named this cañon, has been supposed to have had its origin in the sudden opening of a rift in the earth's crust by subterranean forces; but this supposition has been shown by Mr. A. J. C. Molyneux to be untenable.' The result of my own investigation has been to confirm Mr. Molyneux's conclusion that the river has itself excavated this extraordinary chasm in its rapid descent from the interior plateau. $^{2}$ The evidence is so clear on this point that we need have no hesitation in considering the upper part of the gorge--with which alone we are at present concerned-to be directly due to the slow recession of the great waterfall.

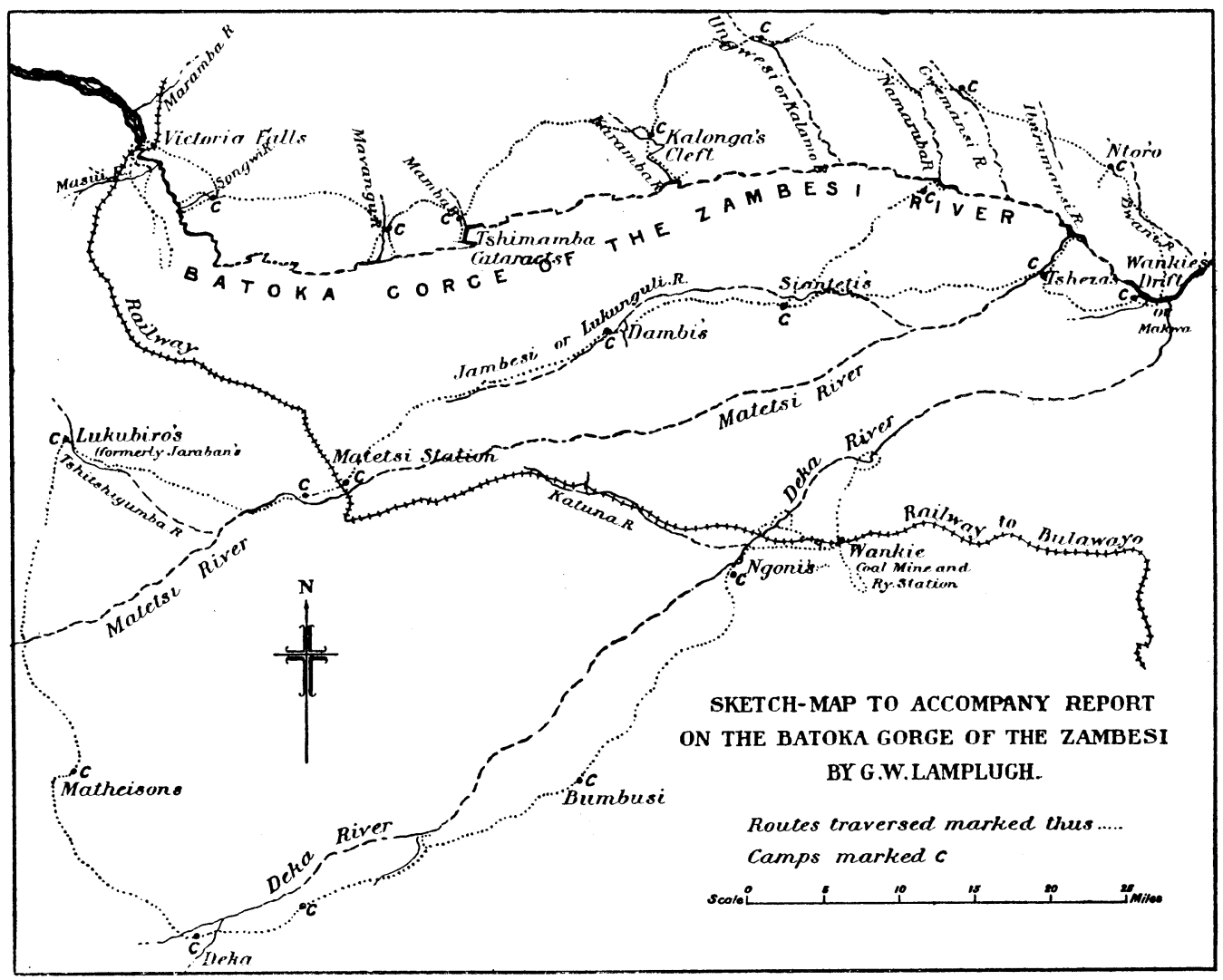

FlG. 1.

Reproduced by the courtesy of the Council of the British Association.

Throughout its length, the Batoka Gorge has been excavated entirely in a great series of basalts-the "Batoka Basalts" of Molyneux--which represents a succession of ancient lava-flows, and the same rocks are known to extend for many miles north and south of the river, and also far to the westward of Victoria Falls. These basalts frequently include large amygdales of chalcedonic, agate and jasper, due to the infilling of the original steam-cavities by silica; and these chalcedonic

1 Geograph. Journ., Jan., 1905, p. 40.

2 See "Abstract of a Report on the Batoka Gorge," Nature, vol. lxxiii (Nov. 30th, 1905), pp. 111-114, also Rep. British Assoc. for 1905, p. 292 
amygdales have yielded the material from which some of the implements have been made.

In the immediate neighbourhood of the Falls, and in many other parts of the region which I traversed, both north and south of the Batoka Gorge, wide areas are deeply covered with red sand, evidently equivalent to the "Kalahari Sand" of Dr. S. Passarge, ${ }^{1}$ which overlies the basalt in broad smooth " bults" or swells, and overlaps the slopes of the old Zambesi Valley on both sides of the river above the Falls. This sand is evidence of a former period when the rainfall was less than at present and when the whole region was in the state of bare desert. The base of the sand is frequently indurated, and in some places, between the sand and the basalt, there occurs an irregular band of quartzite, sometimes several feet in thickness, rough and full of holes, but with a dense chalcedonic or cherty structure in its more solid parts. This quartzite has evidently been formed by the cementing agency of silica-charged water. As Colonel Feilden has noted, many of the stone implements are made from this quartzite.

\section{General Distribution of the Implements.}

The broad shallow valley occupied by the Zambesi above the Falls does not cease at the great cataract, but is distinctly traceable as an open outer valley for several miles below this point, with the zigzagging Batoka Gorge forming an inner trench upon its floor (Fig. 2). It was upon the bottom of this broad outer valley that most of the implements in my collection were found, and they were scattered almost as abundantly upon it below as above the Falls. The conditions of their occurrence suggest that the river probably flowed at its higher level over their present sites when the implements were deposited, and that the upper part of the gorge has been since excavated. If this be indeed the case, we must assign to them a very considerable antiquity.

It may here be noted that a striking characteristic of the Zambesi, and indeed of all other South African rivers which I had an opportunity to examine, is the extraordinary sparsity of their fluviatile deposits. The thick benches of rivergravel and deep accumulations of loam and silt that we are accustomed to find under like conditions in Europe and North America are, so far as my experience goes, curiously wanting in the interior of South Africa; and we find, instead, that the decomposing rock is usually quite close to the surface on the old river-terraces, and that the fluviatile deposits are represented by a mere sprinkling of pebbles or, at the most, by only a few feet of river-borne material. In no place on the old Zambesi platform that came under my observation was there a continuous or measurable layer of gravel, but merely a more or less attenuated surface-sprinkling of pebbles, with occasionally a foot or two of loam; and similar conditions ruled generally in the smaller valleys.

Under these circumstances it is of course much more difficult to determine the antiquity of the implements from their position, as they nearly all lie at the

' Die Kalahari, Berlin, 1904. 
surface and there is very little chance of finding direct stratigraphical evidence relating to them. In one case only, to be described presently, did I find an implement actually buried in alluvium. The rest were seen lying exposed at the surface, mainly on bare rocky places, and usually associated with a sprinkling of

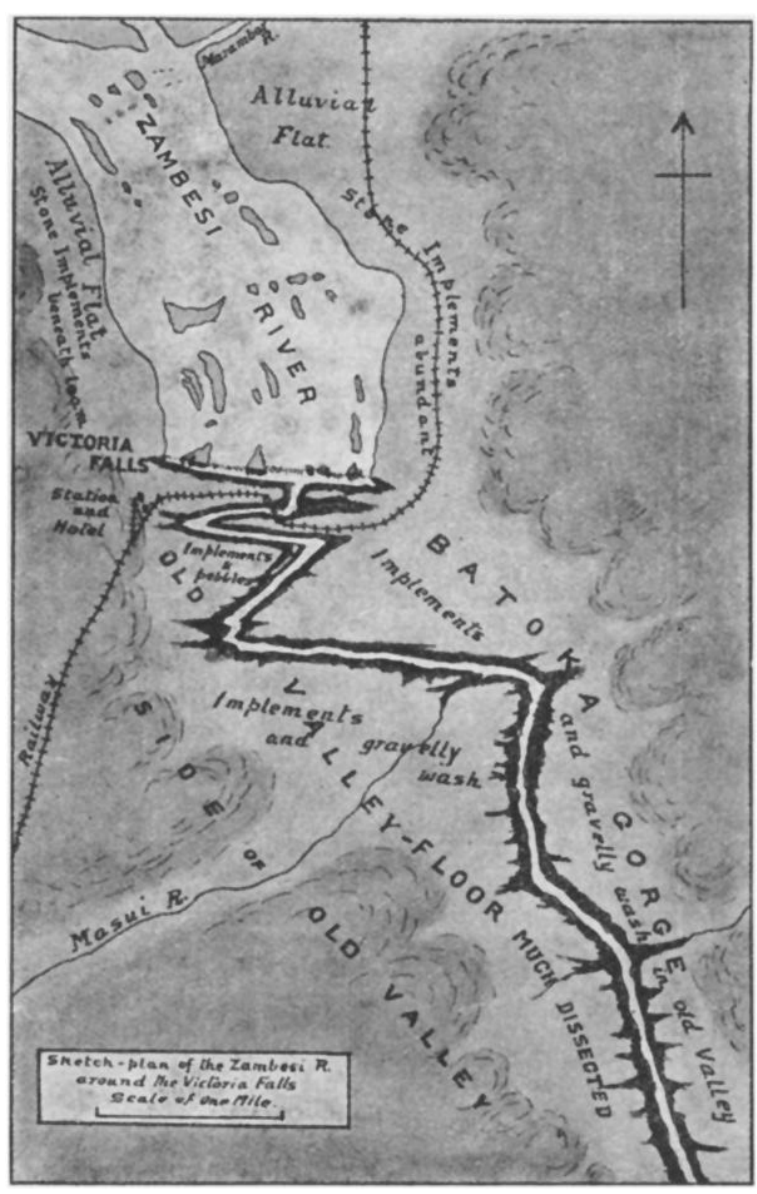

FIG. 2. stones which showed no sign of artificial manipulation.

It is noteworthy also that although I journeyed for many scores of miles over the sandbults, now bush-covered but showing much bare ground, I did not find a single implement upon them; and this experience is borne out by the observations of Colonel Feilden, ${ }^{1}$ who closely examined the sandy tracts near the Falls. Neither did I find any implements on the treeless grassy flats, swampy in the wet season, which occur in every part of the plateau that I visited. These flats are generally underlain by a dark tenacious loami or clay of no great thickness, apparently derived in part from decaying vegetation, but mainly from the decomposition of the basalt.

It is possible, however, that, if implements were very sparsely scattered in the sand and loam, though difficult to find in situ, they might become conspicuous at the underlying rock-surface, if concentrated upon it by the stripping away of the finer particles by an agency that was not powerful enough to remove the heavier bodies. The abundance of the implements on some of the sites in the Zambesi Valley near the margin of tracts of sand and loam was rather suggestive of some such concentration.

General Character of the Implements.

Although at most of the implementiferous sites it was easy to find specimens that showed undoubted artificial working, these were always associated with a

' op. cit. 
much larger number of chipped stones in which the evidence for design was very slight, and also with stones of like composition that showed no trace of artificial fracture. Even in the better examples the workmanship is always rough and crude, and the resultant implement indifferently shaped. 'Yet many of the specimens show a secondary chipping which corresponds more nearly to rough European Neolithic work than to the earlier Palæolithic method. A few examples are figured on Plate XV to show the prevailing characters, but these are mainly representative of a grade above the general average. Indeed the whole of my collection consists principally of the better specimens selected from among the very much larger number that were rejected, though a few examples of the cruder work were retained.

Some of the implements bear a rough resemblance to types common in Europe, but I think that this is probably accidental. At any rate, I searched without avail for anything comparable to the Neolithic arrow-heads, celts etc., with which I am acquainted. Neither did I find anything resembling the Palæolithic hache, though I believe that something of this kind has been found by a later investigator.

It appeared to me that, in the majority of the Zambesi implements which passed under my observation, the object of their fabricators was simply to obtain a sharp curved edge in order that the stone might be used in the hand as a cuttingtool ; and that as soon as an edge of this kind was attained, no further work was done on the implement.

In their present condition, a few of the implements seem to have been waterworn, and many are characterised by a highly glazed or polished surface, which in some examples is most striking and peculiar. To these secondary characters reference will again be made when the probable age of the instruments is discussed.

\section{Implementiferous Sites.}

I first found the implements near Victoria Falls on the low ground bordering the eastern side of the river, between it and the new railway. The worked stones occur here very abundantly upon the low bosses of weathered basalt that rise slightly above the alluvial soil of the flat in the angle between the Zambesi and its tributary the Maramba, which flows to it from the north and has its confluence some two miles above the Falls. Along the line of the railway the rocky ground continues to be richly implementiferous up to the edge of the grassy flats of black loam that intervene as we approach the place where the railway crosses the Maramba; and a large proportion of the specimens in my collection were obtained from these sites.

The implements were mostly found interspersed among rounded pebble-like stones of similar materials that were sprinkled freely over the rocky surfaces; and, as some of the implements themselves are more or less worn and are generally highly glazed, the whole assemblage looked not unlike a scantily developed rivergravel. 
In the west bank of the Maramba, some two or three miles above the railway crossing, where the stream is confined between well-defined banks, I found the single implement obtained from beneath the surface, to which reference has been already made. This specimen, illustrated in Plate XV, Fig. 1, is one of the most shapely in the whole collection. The following section of the river-bank at this place will serve to indicate the conditions under which it occurred.

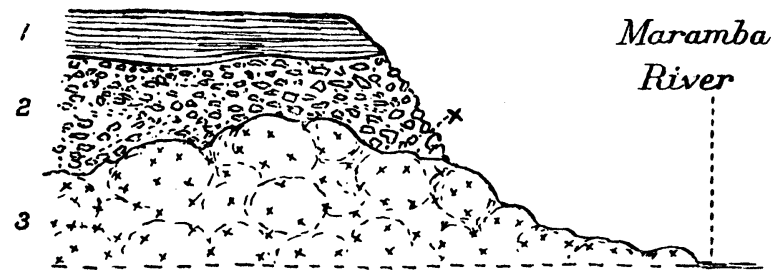

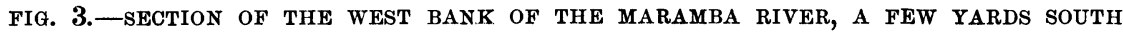
OF THE WAGON-DRIFT NEAR LIVINGSTONE.

1. Brown earthy loam, 2 to 3 feet thick. A shard of coarse earthenware occurred at the base of this loam, 3 feet below the surface.

2. Irregular pockets of coarse gravel, up to 4 feet in thickness, composed mainly of partly worn lumps of "surface-quartzite," chalcedonic pebbles and much-weathered fragments of the subjacent basalt.

The stone implement (PlateXV, Fig. 1) was found in this gravel at a depth of 5 feet from the top of the bank.

3. Amygdaloidal basalt, forming the bed of the stream and the lower part of its banks.

The loam (1) of this section is equivalent to the loam of the grassy flats mentioned above and is probably still within reach of the river-floods and therefore may be of recent accumulation. But the gravel (2) which contained the implement rests directly upon basalt and may be of considerable antiquity, as the Maramba has here almost reached its base-level of erosion in relation to the Zambesi above the Falls. In the course of time, however, when by the gradual recession of the Falls the gorge of the Zambesi shall have been cut back till it reaches the confluence of the Maramba, there will be a sudden rejuvenation of this tributary and an immense gain of erosive power. Its lowermost portion will then at once commence to develop a deep subsidiary gorge of its own, like those possessed by the present streams that join the Zambesi below the Falls, and the relics of its alluvial detritus that now borders the stream will eventually be left on a platform 400 feet above the torrent, like the pebbly material that is now found in this situation along the margins of the Batoka Gorge.

Near the landing-place at the Lower Ferry on the western bank of the Zambesi, three quarters of a mile above the Falls, a narrow loamy flat adjacent to the river has been trenched in places by shallow rain-gullies, which reveal some patches of gravel beneath two or three feet of loam. In these gullies I found a few worked flakes which had evidently been derived from the gravel, but did not discover any of these actually in situ. (See Fig. 2.)

Below the Falls I found the flaked stones in plenty on the ancient river-flat 
bordering the edge of the gorge on both sides, and here again they were nearly always associated with patches of thinly sprinkled chalcedonic and cherty detritus. I surmised at first that this gravelly material might be simply a residuum of the durable amygdales remaining nearly in place after the rotting away of amygdaloidal basalt, but further examinations showed that, at any rate in some cases, this could not be so, as the material was sometimes overspread upon basalt which did not possess the amygdaloidal character, and, moreover, along with the jaspers, agates and chalcedony of the amygdaloids, there were generally many fragments of the peculiar cherty "surface-quartzite" to which reference has been already made. In these places the gravelly detritus had evidently undergone transportation, and probably by the agency of the Zambesi itself before the adjacent portion of the gorge was cut. In a few instances, however, there was an alternative possibility that the transport may have been effected by tributary streams.

On the northern side of the river, scattered patches of this detritus, always associated with flaked stones, occurred frequently in the first nine or ten miles of our journey along the Batoka Gorge, and numerous implements were collected from it between the Falls and the Songwi River, six miles distant, and again between the Songwi and the Kapandi River, three miles farther eastward. (Fig. 1.)

On the opposite or south-western side of the gorge, patches of cherty and chalcedonic detritus, yielding many implements, occur here and there for at least five miles below the Falls, beyond which I had no opportunity for examining the plateau bordering the river. A readily accessible site in this quarter is the narrow flat-topped spur between the sharp zigzag of the gorge, about a mile southeast of the Falls Hotel, and here I found a few well-rounded pebbles along with the usual shapeless subangular fragments and the chipped flakes. That my collection contains only a few specimens from this side of the Zambesi, must not be taken to indicate a relative scarcity of the implements; it merely implies that I collected less keenly here than during my earlier traverse of the country north of the river, when the discovery was still novel, the superabundance of material, of course, soon producing its usual damping effect. For the same reason, the higher average of workmanship shown by these few examples denotes only that the collector's standard was raised and the rougher specimens more freely rejected.

Of the remaining implements in my collection, from localities other than those already mentioned, several are from the little valley of the Mamba River on the northern side of the Zambesi, 28 miles east-south-east of the Falls. Here the flaked stones were abundant around our camping place, which was in the valley within a mile of its junction with the Batoka Gorge, on a rocky flat between craggy sides 60 or 70 feet high, the present bed of the Mamba being excavated a further 15 or 20 feet below the level of this flat. The gorge of the Zambesi is here sunk to about 600 feet below the level of the plateau, and the Mamba at a short distance below our camp makes a terrific leap into a gloomy 
chasm through which it flows into the main gorge. In this region the outer valley of the great river, if it ever existed, is no longer clearly recognizable, as the dissection of the plateau, consequent upon the rejuvenation of the drainage, has reached a stage at which the whole country bordering the river is broken into an intricate maze of ridges and cañons.

The implements obtained from this site differ somewhat markedly from those collected in the country to the west where the old outer valley of the Zambesi is not yet obliterated. Their average size is smaller; they show rather finer flaking; and they are without the high glaze or burnish so prevalent in those from the more westerly sites. In spite of these differences, however, the implements are of the same general type and shape. (Plate XV, Fig. 10.)

The position of the flaked stones in this instance is compatible with only a moderate degree of antiquity, since the little valley itself cannot be very old; and since it is probable that these implements are newer than those of the old Zambesi Valley previously described, they are an illustration of the conservatism of type which characterizes the stone implements of South Africa.

Our route eastward from the Mamba usually lay at a greater distance from the Zambesi, and although a sprinkling of chalcedonic detritus was still occasionally observed, very few artificially flaked stones were seen, and none collected. That this indicates a marked, though not exclusive, localization of the implements to the vicinity of the Zambesi will be evident from the following observations culled from my notes on the journey.

Near the Karamba River, about 35 miles east-south-east of Victoria Falls, I noted "much chalcedony in places on surface, but no chips seen"; on the next march eastward- " a few poor 'flint' chips seen, but not good and not plentiful "; and again, at about 70 miles from the Falls-"a few doubtful chips en route." One fresh-looking chip was collected near Wankies Drift, some 75 miles distant from the Falls, where we again reached the Zambesi.

My observations during a subsequent journey on the southern side of the river from Wankie's Drift to Matetsi, thence southward across the broken plateau to Deka, and from Deka to Wankie Coal Mine, a distance in all, with detours, of over 250 miles, served to confirm the relative scarcity of the flaked stones in the country distant from the Zambesi, though as this journey was made partly on horseback the ground was less closely examined than during the more northerly trek, which was made afoot. I noticed a few poorly-worked chips in the Matetsi Valley about one and a half miles south-west of the railway bridge, the site being as usual in the vicinity of permanent water, on a rock platform 30 or 40 feet above the present stream. But in several places toward the head-waters of the Matetsi, and on the low watershed between it and the Deka River, where chalcedonic detritus was abundant, I failed to find any certain indication of artificial chipping, though an experienced archæologist might possibly have been able to recognise it in some of the "doubtful" specimens. Respecting the upper part of the Deka Valley my notes state " no chips found in this district, though 
looked for, and agates not rare"; and no better results were obtained from the places examined lower down the valley.

I may here mention a very modern flake which I picked up on the outskirts of a native kraal on the Lukunguli or Jambesi River, a large tributary of the Matetsi. The specimen is of interest in showing that the natives still occasionally prepare flakes for cutting purposes, not very dissimilar in shape from the smaller of the ancient implements. The object, as was pointed out by a speaker when the implements were exhibited at the Johannesburg meeting, proves to be a chip of porcelain which has apparently been struck from a telegraph-insulator. The place where I found the specimen is 30 miles or more from the nearest telegraph line, but the natives travel for very much longer distances to work on the railway.

It is worthy of note that Chapman, in his record of a journey across the Kalahari in the year 1862, describes how one of his Damara followers skinned a buck with a sharp stone, and the author adds that "an edged stone is not a bad substitute for a knife." The term "edged stone" here used is perhaps the best short description that could be given of most of the implements in my collection.

\section{Concluding Notes.}

Besides any strictly archæological evidence that may be afforded by the workmanship of the Zambesi implements, which I am not qualified to discuss, there are other factors to be taken into account in considering the question of the antiquity of these " edged stones" which I propose briefly to recapitulate.

The first and most important of these is whether the implements form an integral part of the gravelly detritus with which they are associated, or whether they have been shaped subsequently to its deposition. It is evident that the Batoka Gorge has been cut backward very slowly. Owing to the resistant character of the solid basalt, the river has been compelled to concentrate its energies mainly along the joints and other planes of weakness that intersect the rock, and has picked out its channel along them even when their direction lies athwart its general course, thus giving rise to the singular zigzags of the gorge, and thereby greatly lengthening its channel. The carving out of these zigzags must have required a very long time; and the high antiquity of the shallow outer valley within which they lie is further indicated by the presence of the red "Kalahari Sand" upon its slopes.

Therefore if the implements that occur on top of the spurs between the zigzags, and in corresponding situations for several miles below the Falls, were indeed deposited there by the river when it still flowed over these sites, they must be of very great antiquity. The state of preservation of the implements, though favourable to this supposition, is not in itself convincing. Some few, like the exarnples shown in Plate XV, Figs. 2 and 7, are so much worn as to suggest that they have been rolled along the river bed; and most have had the sharp

1 Travels in the Interior of South Africa (London, 1868), vol. ii, p. 59. 
angles of the original chipping more or less smoothed and blunted, as in Figs. 3, 8, and 9. But this blunting may have been done, in part at least, by the same agency that produced the wonderful burnish or glaze that is so remarkable on many of the specimens (e.g., Plate XV, Figs. 2 and 11), which cannot, I think, be assigned to the direct agency of the river, but has probably been caused by some subærial operation. ${ }^{1}$ The burnishing action of wind-borne sand is well known, but seems inapplicable in this case, as the glaze is spread evenly over every surface, including all the minor irregularities, without any trace of the unequal rasping of the sand-blast; and, moreover, the bush-covered country in which the implements are found, is not, under present conditions, open to sand-drift. It seems more probable that the phenomenon is akin to the "desert varnish" with which the water-worn rocks of all the stream beds of this region are glazed, and that it represents a thin mineral film deposited by evaporating moisture which carried mineral substances in solution. The "surface-quartzites" themselves are sufficient evidence that the solution and re-deposition of silica by ground-water has been prevalent on an extensive scale in the region; and it seems quite likely that the implements of chert and chalcedony have been affected by this reaction, in which case the burnish might be regarded as an extreme type of patination. However, even if the blunting of the chipped stones be assignable to this process and not to direct river-wear, it must still surely have been a slow process and must indicate a considerable antiquity for them.

As already remarked, it is unfortunate that the curiously scanty development of river-gravel in the region almost precludes the chance of obtaining direct stratigraphical evidence. In the one instance where such evidence was available, viz., that at the Maramba above described, there was no doubt that the implement was actually embedded in the river-gravel, but it was not possible to prove with certainty that the gravel was very old, since it still forms part of the existing river-flat. It should be noted that this implement has its chipping quite freshly preserved and is neither worn nor polished, which lends support to the idea that the peculiar condition of the surface specimens is due to some subærial agency.

Setting aside the condition of the implements, it might perhaps be possible, in the case of those found above the Falls and in the tributary valleys, to explain their present position by supposing that the ancient inhabitants of the country, when they needed cutting tools, resorted to the places where suitable stone was plentiful, and there prepared, used, and discarded the implements. It is certainly remarkable how often, in different parts of the world, we find worked stones abundantly near the spot where the raw material occurs, while where such material is absent in neighbouring districts apparently as suitable in every respect for human occupation, they may be quite rare, and it is evident that primitive man did not habitually carry his ruder implements far from the place where he shaped

1 It has been suggested to me, however, by my friend, Prof. T. G. Bonney, that the burnishing may have been produced by long-continued drifting of very fine silt or mud over the surface of the implements, either by wind or water action. 


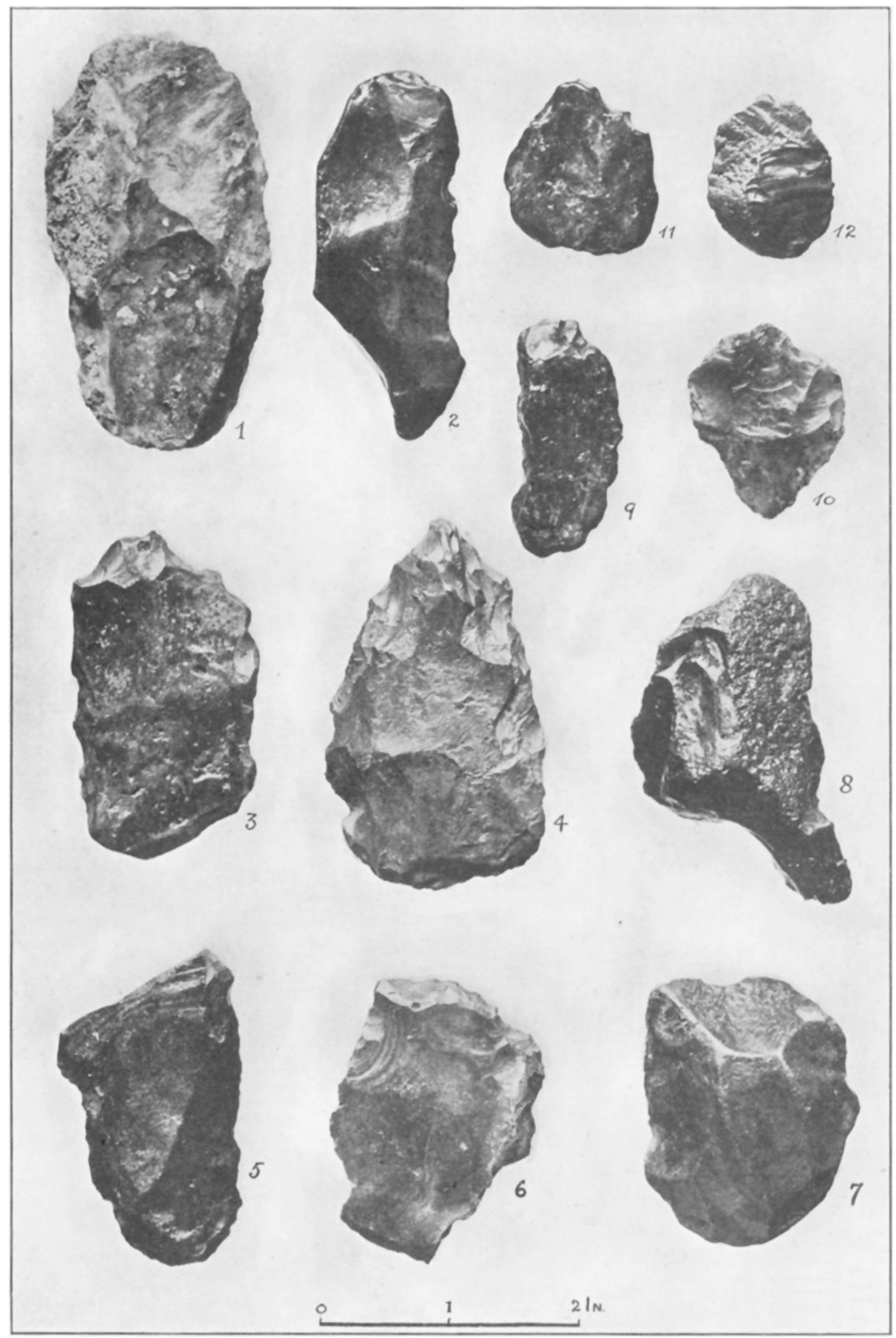

STONE IMPLEMENTS FROM THE ZAMBESI VALLEY. 
them. But I do not think that this supposition can be applied to the sites in the extremely rugged ground bordering the gorge below the Falls, where in the dry season there is no accessible water, and, so far as I could judge, no better material than that of the more convenient sites to induce the native to establish his working places there.

Taking the whole evidence into consideration I therefore lean to the opinion that most of the implements were left in their present position when the Zambesi flowed in its higher valley for some distance below the present Falls. At any rate, the facts are sufficient to justify a more thorough investigation of the subject than I was able to undertake. 